\title{
Pengaruh Penggunaan Pop-Up Book Terhadap Hasil Belajar Siswa Pada Materi Konsep Siklus Air
}

\author{
Fitriana Khoirun Nisaa', * \& Zuanita Adriyani \\ Universits Islam Negeri Walisongo Semarang \\ *Penulis korespondensi: fkn306@gmail.com \\ DOI : https://doi.org/10.21580/jieed.v1i2.8238 \\ Received: 2021-05-28, Revised: 2021-10-16, \\ Accepted: 2021-11-06, Published: 2021-11-06
}

\begin{abstract}
Abstrak
Penelitian ini dilatarbelakangi oleh masalah penggunaan media pembelajaran di Madrasah Ibtidaiyah yang masih kurang bervariasi. Penelitian ini bertujuan untuk mengetahui pengaruh penggunaan media pop-up book terhadap hasil belajar siswa pada materi konsep siklus air, dan respons siswa terhadap penggunaan pop-up book. Metode penelitian ini adalah quasi eksperimen. Sampel penelitian ini adalah Kelas V Sift 1 sebagai kelas eksperimen dan kelas V Sift 2 sebagai kelas kontrol. Hasil analisis data menggunakan rumus korelasi biserial memperoleh hasil rbis $(0,711171)>$ rtabel $(0,32)$ untuk taraf signifikan $5 \%$ maka $\mathrm{H}_{0}$ ditolak, Ha diterima. Pengaruh penggunaan media pop-up book terhadap hasil belajar siswa pada materi konsep siklus air adalah sebesar 50,41\%, dan sisanya dipengaruhi oleh variabel lain. Respon siswa terhadap penggunaan pop-up book adalah sebesar 88,26\%, yaitu berada pada kategori sangat baik.
\end{abstract}

\section{Kata Kunci: Pop-up book, Pembelajaran Konsep Siklus Air, Media Visual}

\section{The Effect of Using Pop-Up Books on Learning Outcomes of the Water Cycle Concept}

\begin{abstract}
This research is motivated by the problem of using learning media in Madrasah Ibtidaiyah which is still less varied. This study aims to determine the effect of using pop-up book media on student learning outcomes on the water cycle concept material, and student responses to the use of pop-up books. This research method is quasiexperimental. The sample of this research is Class $V$ Shift 1 as the experimental class and class $V$ Shift 2 as the control class. The results of data analysis using the biserial correlation formula obtained the results of rbis (0.71171) > rtable (0.32) for a
\end{abstract}


significant level of 5\%, then $\mathrm{HO}$ was rejected, Ha was accepted. The effect of using popup book media on student learning outcomes on the water cycle concept material is $50.41 \%$, and the rest is influenced by other variables. Student response to the use of pop-up books is $88.26 \%$, which is in the very good category.

Keywords: pop-up book, media visual, teaching water cycle concept

\section{PENDAHULUAN}

Pembelajaran merupakan salah satu proses yang menentukan keberhasilan dunia pendidikan. Proses pembelajaran ditandai dengan adanya interaksi edukatif yang terjadi antara siswa, guru, dan sumber belajar untuk mencapai tujuan pembelajaran yang telah ditentukan (Martias et al, 2019). Tujuan pembelajaran yang harus tercapai dipengaruhi oleh berbagai macam komponen-komponen penting yang harus dipersiapkan dengan matang, salah satunya adalah media pembelajaran.

Hasil studi pendahuluan penulis menunjukkan bahwa proses belajar mengajar IPA di kelas V Madrasah Ibtidaiyah Matholiul Falah Juwana belum mengajak siswa berperan aktif di dalam proses pembelajaran. Wali Kelas V menyatakan jarang menggunakan media hasil dari kreativitasnya. Beliau lebih condong menggunakan media yang ada di buku cetak dan papan tulis sebagai perantara untuk menyampaikan materi pelajaran. Metode pembelajaran yang digunakan guru juga kurang variatif, ia lebih sering menggunakan metide ceramah dan latihan soal. Model pembelajaran ini telah membuat peserta didik kurang semangat dan jenuh saat mengikuti pembelajaran IPA, dan guru juga kurang mengetahui tingkat penguasaan siswa.

Media pembelajaran adalah bahan, alat, dan saluran yang digunakan untuk mendukung kegiatan belajar dan mengajar (Batubara, 2021). Penggunaan media menjadi sangat penting untuk membantu peserta didik untuk mengembangkan ide dan gagasan mereka sehingga mereka mampu berpikir kreatif dan inovatif dalam menguasai konsep materi pelajaran.

Salah satu alternatif media yang dapat digunakan oleh guru untuk memudahkan peserta didik dalam proses pembelajaran yaitu dengan menggunakan media pop-up book. Pop Up Book merupakan buku yang bisa bergerak dan dapat melakukan interaksi melalui penggunaan mekanisme kertas seperti lipatan, slide, gulungan, dan roda (Dhamayanti, 2019).

Menurut Dzuanda (dalam Sholeh, 2019) pop-up book adalah sebuah buku yang memiliki bagian yang dapat bergerak atau memiliki unsur 2 dimensi dan 3 dimensi serta memberikan visualisasi cerita yang menarik, mulai dari tampilan gambar yang dapat bergerak ketika halamannya dibuka. Menurut Kurniawati pop-up book adalah 
sebuah buku yang memiliki bagian yang dapat bergerak atau memiliki unsur 3 dimensi yang dapat bergerak ketika halamannya dibuka (Wulandari, 2019).

Menurut Montanaro, pop-up book merupakan sebuah buku memiliki bagian yang berpotensi bergerak dan memiliki unsur 3 dimensi yang dapat membuat siswa tidak bosan dalam proses belajar mengajar dan memberikan kemudahan bagi siswa dalam menyerap pemebalajaran (Barsihanor dkk, 2020). Jadi dapat disimpulakan media pop-up book merupakan media yang menarik serta membuat proses pembelajaran lebih fokus sehingga dapat mempengaruhi penguasaan konsep.

Penguasaan konsep adalah kemampuan yang dimiliki siswa setelah mereka menerima pengalaman belajar dalam proses pembelajaran. Penguasaan konsep didefinisikan sebagai kemampuan dalam menyerap arti materi atau bahan yang dipelajari sehingga dapat disajikan dalam bentuk yang dapat dimengerti dan mampu memberikan interpretasi serta mampu mengklarifikasikannya kedalam hubungan konsep dan makna dari konsep tersebut (Hamdani dkk, 2012). Penguasaan konsep adalah kemampuan untuk menyerap arti dari materi yang dipelajari sehingga memungkinkan seseorang menerapkan penguasaanya dalam berbagai keperluan (Widia, 2020.).

Menurut Winkel penguasaan konsep sebagai suatu pemahaman dengan menggunakan konsep, kaidah dan prinsip. Penguasaan konsep menjadi salah satu aspek dalam mengukur hasil suatu pembelajaran (Suranti, 2017). Penguasaan konsep juga dapat didefinisikan sebagai kemampuan dalam memahami arti materi atau bahan yang dipelajari sehingga dapat disajikan dalam bentuk yang dapat dimengerti dan mampu memberikan interpretasi serta mampu mengklarifikasikannya kedalam hubungan konsep dan makna dari konsep tersebut (Hendayani, 2019).

Ada beberapa bagian dari kompetensi kognitif salah satu diantaranya adalah peguasaan konsep. Pengukuran penguasaan konsep dalam penelitian ini adalah kemampuan kognitif siswa yang merujuk pada indikator taksonomi Bloom (Sari, dkk , 2017). Kategori-kategori dalam dimensi penguasaan konsep tersebut meliputi, C1 (mengingat), C2 (memahami), C3 (mengaplikasi), C4 (menganalisis), C5 (mengevaluasi), dan C6 (mencipta). Dari beberapa argumen diatas dapat disimpulkan bahwasannya tujuan inti dari suatu pembelajaran adalah penguasaan konsep.

Siklus air merupakan sirkulasi (perputaran) air secara terus-menerus dari bumi ke atmsofer, lalu kembali ke bumi. Pada materi siklus air didalamnya terdapat beberapa pembahasan diantaranya yaitu tahapan-tahapan dan proses-proses terjadinya daur air. Tahapan Siklus air terjadi melalui proses penguapan (evaporasi), pengendapan (presipitasi), dan pengembunan (kondensasi) (Kusumawati Heny, 2017). 
Materi siklus air penting diajarkan di sekolah dasar dengan tujuan agar siswa mengetahui dan memahami tentang cara bersikap terhadap alam dan memiliki sifat yang peduli terhadap alam. Namun tidak memungkinkan jika siswa diminta untuk mengamati proses siklus air yang terjadi secara langsung di alam, sehingga dalam materi siklus air ini dibutuhkan media yang dapat memfasilitasi kegiatan siswa (Putra dan Suniasih, 2021). Mengingat daya serap menghafal dan memahami materi antar siswa berbeda maka dibutuhkan media pendukung untuk memudahkan proses pembelajaran agar dapat berpengaruh pada penguasaan konsep siswa.

Hasil prariset yang dilakukan oleh peneliti di MI Matholiul Falah Desa Langgen Harjo, Kecamatan Juwana, Kabupaten Pati pada tanggal 5 oktober 2020 dari 5 responden, didapatkan 3 dari 5 (60\%) siswa menyatakan bahwa masih kesulitan dalam memahami pembelajaran IPA. Hal tersebut menyebabkan Penguasaan konsep yang diperoleh rendah karena bergantung pada cara penyampaian materi dan media yang digunakan. Oleh karena itu diperlukan suatu media pembelajaran yang diharapkan mampu mempengaruhi Penguasaan konsep peserta didik.

\section{METODE}

Penelitian ini dilaksanakan di Madrasah Ibtidaiyah Matholiul Falah Juwana. Pengambilan data dan penelitian dilaksanakan pada tanggal 8 Februari 2020 sampai 8 Maret 2020. Jenis penelitian yang digunakan adalah penelitian kuantitaif dengan pendekatan eksperimen. Desain yang digunakan dalam penelitian ini adalah quasi experimental. Rancangan penelitian ini menggunakan desain Nonequivalent Control Group Design. Desain Nonequivalent Control Group Design dalam desain ini kelompok eksperimen maupun kelompok kontrol tidak dipilih secara random (Sugiyono, 2008).

Populasi dalam penelitian ini adalah seluruh siswa kelas 5 MI Matholiul Falah, yang terdiri dari 1 kelas yang terbagi menjadi 2 sift. Sift pertama terdiri dari 18 siswa, sift keduat terdiri dari 18 siswa. Teknik pengambilan sampel yang digunakan adalah simple random sampling (Sugiyono, 2015). Pengundian kelas yang terambil pertama, yaitu kelas 5 sift 1 ditetapkan sebagai kelas eksperimen yang pembelajarannya menggunakan media pembelajaran Pop-Up Book dan yang terambil kedua yaitu kelas 5 sift 2 ditetapkan sebagai kelas kontrol yang pembelajrannya tanpa menggunakan media pembelajaran.

Teknik pengumpulan data dalam penelitian ini menggunakan lembar tes obyektif. Lembar tes berupa soal pilihan ganda dengan opsi A, B, C, dan D. Teknik pengumpulan data dalam penelitian ini dengan menggunakan teknik tes (pretest dan posttest). Instrumen tersebut berisi soal kognitif materi siklus air yang terdiri dari tes objektif pilihan ganda sebanyak 30 soal. Kisi-kisi instrumen disusun berdasarkan indikator materi siklus air. 
Instrumen soal sebelum digunakan untuk pretest dan posttest diuji cobakan kepada siswa kelas VI MI Matholiul Falah Juwana. Dari hasil ujicoba didapatkan hasil diperoleh 20 soal pilihan ganda yang valid dan reliabel. Perhitungan diperoleh dengan cara menghiting $r_{\text {pbis. }}$. Dengan taraf signifikan $5 \%$ dan $\mathrm{N}=23$ diperoleh $r_{\text {tabel. }}=$ 0,413 . Butir soal dikatakn valid apabalila nilai $r_{p b i s}>r_{\text {tabel. Sedangkan instrumen }}$ dikatakan reliabel $r_{\text {tabel }}>r_{\text {hitung. }}$ Dari perhitungan uji reabilitas didapatkan hasil 0,8516 . Nilai koefisien korelasi tersebut pada interval 0,8-1,0 dalam kategori sangat tinggi. Soal yang valid dan reliabel tersebut digunakan untuk pretest dan posttest.

Instrumen yang digunakan dalam penelitian ini adalah analisis uji validitas dan reliabilitas, daya beda dan tingkat kesukaran sedangkan untuk analisis hasil, peneliti menggunakan Uji normalitas, Uji homogenitas, Uji T-Test, dan Uji korelasi biserial. Sebelum instrumen dijadikan alat pengumpulan data diperlukan uji instrumen terlebih dahulu. Hal ini bertujuan untuk menguji tigkat validitas dan reliabilitas soal. Teknik yang digunakan untuk menguji validitas instrumen pretest dan posttest pada penelitian ini menggunakan rumus korelasi biserial (Arikunto, 2013).

\section{HASIL}

Langkah pertama penelitian ini adalah melakukan pre-test dan uji prasyarat untuk mengetahui apakah data berdistribusi normal atau tidak. Data yang diambil adalah dari nilai pretest siswa kelas V MI Mathaliul Falah Juwana, yang diberikan sebelum kedua kelas diberikan perlakuan. Hasil perhitungan uji normalitas data awal pada kelas V sift 1 diperoleh $x^{2}$ hitung $=10,83542$, sedangkan pada kelas V sift 2 diperoleh $x^{2}$ hitung $=10,44782$. Selanjutnya harga ini dibandingkan dengan $x^{2}$ tabel dengan dk 6-1 = 5 dengan taraf signifikasi 5\% yang ditetapkan $x^{2}$ tabel = 11,070. Karena $x^{2}$ hitung lebih kecil daripada $x^{2}$ tabel maka distribusi data nilai statistik siswa kelas V sift 1 dan V sift 2 dinyatakan berdistribusi normal. Adapun hasil perhitungan uji homogenitas diperoleh varians kelas V Sift 1 sebesar 71,89 dan kelas V Sift 2 sebesar 64,05 sehingga $F_{\text {hitung }}$ 0,89 dan $F_{\text {tabel }} 2,27$. Hal tersebut menunjukkan bahwa $F_{\text {hitung }}<F_{\text {tabel }}$ maka kedua kelas homogen.

Adapun hasil uji perbedaan dua rata-rata menggunakan uji t memperoleh $t_{\text {hitung }}$ sebesar 3,51 dan $t_{\text {tabel }}$ sebesar2,032 dengan taraf signifikansi $5 \%$. $t_{\text {hitung }}$ lebih besar daripada $t_{\text {tabel }}$ sehingga $H_{a}$ diterima dan $H_{0}$ ditolak sehingga rata-rata kelas eksperimen berbeda dengan rata-rata kelas kontrol atau rata-rata kelas eksperimen lebih baik dibanding rata-rata kelas kontrol. Hal ini dibuktikan dengan perolehan hasil uji t yaitu thitung $>t_{\text {tabel }}(4,00>2,021)$ yang berarti hipotesis kerja (Ha) dalam penelitian ini diterima(Hasanah et al., 2019). Grafik perolehan nilai antara kelas kontrol dan kelas eksperimen di MI Matholiul Falah dapat dilihat pada gambar 1 . 


\section{Gambar 1}

Rata-rata perolehan nilai antara kelas kontrol dan kelas eksperimen

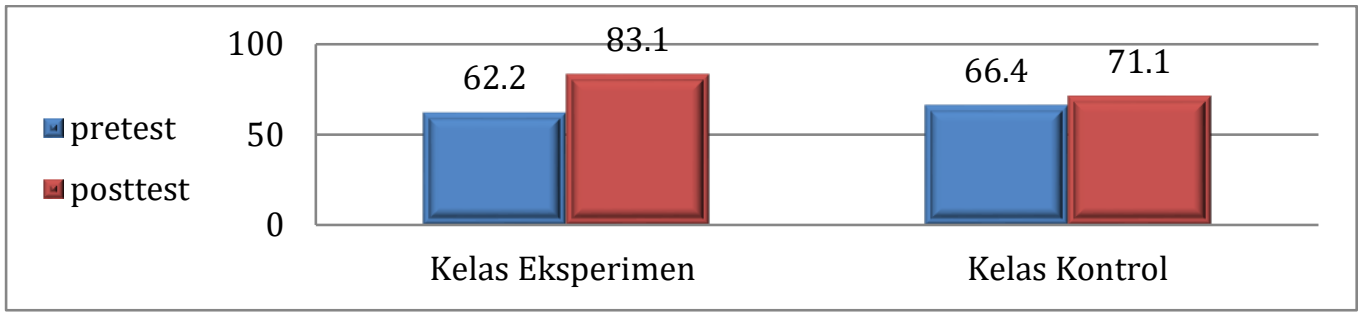

Sumber: dokumen pribadi penulis

Hasil uji korelasi biserial dan koefisien determinasi menunjukkan bahwa koefisien korelasi (rbis) adalah 0,711171, dan dikonsultasikan dengan $\alpha=5 \%$ diperoleh rtabel $=0,32(\mathrm{dk}=36)$, sehingga rbis $>$ rtabel, maka $\mathrm{H}_{0}$ ditolak dan $\mathrm{H}_{\mathrm{a}}$ diterima. Hal ini menunjukkan bahwa Media Pop-Up Book berpengaruh terhadap Penguasaan konsep siswa dengan kriteria yang sangat kuat/tinggi.

Selanjutya adalah mencari besarnya pengaruh yaitu dengan menggunakan rumus dari koefisien determinasi. Berdasarkan hasil perhitungan diperoleh sebesar 50,41\%, sehingga dapat disimpulkan bahwa media pop-up book berpengaruh terhadap Penguasaan konsep siswa dan memberikan konstribusi sebesar 50,41\%, dan sisanya dipengaruhi oleh variabel yang lain.

Adapun hasil respons peserta didik terhadap penggunaan media pop-up book telah memperoleh nilai $88,26 \%$ dengan kriteria sangat baik.

\section{PEMBAHASAN}

Gambar 1 menunjukkan bahwa nilai rata-rata pretest kelas kontrol adalah 66,4 dan kelas eksperimen adalah 62,2. Adapun nilai rata-rata posttest antara kelas kontrol dan kelas eksperimen berbeda. Rata-rata perolehan nilai posttest kelas eksperimen lebih tinggi dibandingkan dengan kelas kontrol. Perbedaan tersebut dapat dikarenakan karena beberapa faktor yang mempengaruhi Penguasaan konsep. Salah satu diantaranya adalah karena penggunaan media pembelajaran

Hasil penelitian ini menyimpulkan bahwa bahwa media pop-up book berpengaruh terhadap penguasaan konsep siswa. penggunaan media pop-up book dapat memberikan pengaruh positif terhadap Penguasaan konsep peserta didik dikarenakan media pop-up book memiliki kelebihan diantaranya yaitu: (a) memberikan visualisasi yang menarik mulai dari tampilan gambar yang memiliki dimensi hingga gambar yang dapat bergerak ketika halamannya dibuka atau bagiannya digeser. (b) memiliki kejutan-kejutan dalam setiap halaman yang dapat mengundang ketertarikan siswa dan mengurangi kejenuhan siswa ketika proses 
pembelajaran (c) memperkuat kesan dan merangsang imajinasi anak di setiap halaman yang disajikan (d) menambah pengetahuan hingga memberikan penggambaran bentuk suatu benda sehingga mudah diingat oleh anak (Sylvia \& Hariani, 2015).

Media pembelajaran yang digunakan di kelas eksperimen adalah media popup book, media tersebut difokuskan pada materi siklus air. Media pop-up book tidak hanya berisi materi siklus air tetapi dilengkapi dengan gambar 3 dimensi yang relevan dan dikaitkan dengan kehidupan sehari-hari sehingga peserta didik lebih mudah memahami materi siklus air yang yang akhirnya berpengaruh terhadap hasil beajar peserta didik. Hal tersebut sesuai dengan pernyataan yang dikemukakan oleh Gerlach Ely mengemukakan bahwa media merupakan suatu hal yang bisa dipergunakan dalam menumpahkan beraneka macam pesan yang ingin disampaikan kepada siswa serta dapat mewujudkan makna pesan yang akan disampaikan(Arsyad, 2014). Dari uraian tersebut dapat menjawab hipotesis bahwa terdapat perbedaan rata-rata nilai siswa kelas V Sift 1 dan kelas V sift 2 dalam Penguasaan konsep. Pembelajaran IPA dengan menggunakan media pop-up book memiliki pengaruh yang lebih baik daripada pembelajaran tanpa bantuan media pop-up book

Setiap peserta didik memiliki respon yang berbeda-beda terhadap pembelajaran yang berlangsung di dalam kelas. Perbedaan respon tersebut dipengaruhi oleh strategi guru dalam mengajar, pemilihan model pembelajaran yang tepat, penggunaan media pembelajaran yang menarik dan lain sebagainya. Besarnya respon peserta didik dapat diketahui, salah satunya dengan penyebaran angket.

Hasil perhitungan yang telah dilakukan diperoleh 88,26\% dengan kriteria sangat baik. Penelitian yang dilakukan oleh Elis Trisdiana Wati dan Ulhaq Zuhdi juga menyatakan bahwasannya penggunaan media pop-up book meraih respon positif dari siswa sebesar 86,79\% dan tergolong sangat baik (Wati \& Zuhdi, 2017). Peserta didik merasa senang mengikuti pembelajaran dengan menggunakan media pop-up book. Selain itu, peserta didik juga dapat memahami materi siklus air dengan menggunakan media tersebut. Respon yang sangat baik tersebut dapat mempengaruhi Penguasaan konsep peserta didik di MI Matholiul Falah Juwana. Hal tersebut dapat dibuktikan dengan perbedaan perolehan nilai pada materi siklus air antara kelas kontrol dan kelas eksperimen. Kelas eksperimen memperoleh nilai yang lebih tinggi dibanding kelas kontrol setelah menggunakan media pop-up book dalam pembelajaran. 


\section{SIMPULAN}

Hasil penelitian ini menemukan bahwa penggunaan media pop-up book lebih efektif dalam meningkatkan penguasaan konsep peserta didik dibandingkan dengan penggunaan buku cetak saja. Respon peserta didik terhadap penggunaan media pop-up book juga berada dalam kategori sangat baik. Oleh karena itu, hasil penelitian ini merekomendasikan kepada guru untuk memvariasikan media pembelajarannya menggunakan media pop-up book.

\section{DAFTAR PUSTAKA}

Arikunto, S. (2012). Dasar-dasar evaluasi pendidikan edisi 2. Jakarta: Bumi Aksara. Arsyad, A. (2014). Media Pembelajaran. PT. Raja Grafindo Persada.

Barsihanor, B., Hafiz, A., KMR, G. N., \& Budi, I. S. (2020). Pembuatan Media Pembelajaran Pop Up Book Bagi Guru Madrasah Ibtidaiyah. JMM (Jurnal Masyarakat Mandiri), 4(4), 588-594.

Batubara, H. H. (2021). Media Pembelajaran Digital (N. A. N. (ed.); 1st ed.). PT. Remaja Rosdakarya.

Dhamayanti, A. K. (2019). Penggunaan Media Pembelajaran Pop Up Book Untuk Meningkatkan Keterampilan Berbicara. Prosiding Seminar Nasional Pendidikan, 1, 1432-1437.

Hamdani, D., Kurniati, E., \& Sakti, I. (2012). Pengaruh model pembelajaran generatif dengan menggunakan alat peraga terhadap pemahaman konsep cahaya kelas VIII di SMP Negeri 7 Kota Bengkulu. Exacta, 10(1), 79-88.

Hasanah, U., Studi, P., Guru, P., Ibtidaiyah, M., Tarbiyah, F., \& Tadris, D. A. N. (2019). Pengaruh Media Pop Up Book Terhadap Hasil Belajar Siswa Pada Mata Pelajaran Ipa Kelas V SD Negeri 99 Kota Bengkulu. 30.

Hendayani, S. (2019). Penerapan Strategi Reciprocal Teaching untuk Peningkatan Pemahaman Konsep Peserta Didik Pada Pembelajaran Ips. JPGMI (Jurnal Pendidikan Guru Madrasah Ibtidaiyah Al-Multazam), 4(2), 102-112.

Kusumawati Heny. (2013). Buku Guru Kelas V Tema 8 Lingkungan Sahabat Kita.

Martias, M., Suriyanto, A. D., \& Triartanto, A. Y. (2019). Membangun Budaya Belajar Mahasiswa Melalui Pengembangan Teknologi Informasi. E-Jurnal Mitra Pendidikan, 3(7), 1010-1021.

Putra, I. K. D., \& Suniasih, N. W. (2021). Pengembangan Media Diorama Materi Siklus Air Pada Muatan IPA Kelas V Sekolah Dasar. Jurnal Imiah Pendidikan dan Pembelajaran, 5(2).

Sari, P. I., Gunawan, G., \& Harjono, A. (2017). Penggunaan discovery learning berbantuan laboratorium virtual pada penguasaan konsep fisika siswa. Jurnal Pendidikan Fisika Dan Teknologi, 2(4), 176-182.

Sholeh, M. (2019). Pengembangan Media Pop-Up Book Berbasis Budaya Lokal Keberagaman Budaya Bangsaku Siswa Kelas IV Sekolah Dasar. Jurnal Gentala Pendidikan Dasar, 4(1), 138-150.

Sylvia, N. I., \& Hariani, S. (2015). Pengaruh penggunaan media pop-up book terhadap keterampilan menulis narasi siswa sekolah dasar. JPGSD, 3(2), 1196-1205. 
Wati, E. T., \& Zuhdi, U. (2017). Pengaruh media pop-up book terhadap hasil belajar siswa tema ekosistem kelas V SDN Karangpilang 1 Surabaya. Jurnal Penelitian Pendidikan Guru Sekolah Dasar, 5(3), 254557.

Widia, W., Sarnita, F., Fathurrahmaniah, F., \& Atmaja, J. P. (2020). Penggunaan Strategi Mind Mapping Untuk Meningkatkan Penguasaan Konsep Siswa. Jurnal Ilmiah Mandala Education, 6(2).

WULANDARI, I. S. R. I. A. Y. U. (n.d.). Pengaruh penggunaan media pop up untuk meningkatkan hasil belajar ipa siswa sd islam taman quraniyah. Jakarta: FITK UIN Syarif Hidayatullah Jakarta. 